\title{
SOUTH NORWALK'S MUNICIPAL ELECTRIC WORKS
}

\author{
By Albert E. Winchester, \\ South Norwalk, Connecticut.
}

This is not a brief in defense of municipal ownership, it is just a little story of an experience in that line, and why, with some thoughts that it has inspired tending toward public service regulation as above ownership. But if it will help, even as a small voice, toward bringing about a better, fairer understanding between those who operate public utilities and those who are served by them, regardless of the far lesser factor of ownership, and if it will give aid to the promotion of consistent public regulation and protection of such utilities, then its mission will have been well done.

There are at least two ways of looking at every proposition and, if it has merit, both may be worthy of fair consideration from varying aspects. No single slant of observation can carry the full weight of truth, and yet each may be faithful to its own viewpoint. Circumspection will eliminate differences which argument alone may only compound.

Prior to 1892 , the electric lighting service of the progressive little city of South Norwalk, Connecticut (now the central part of the new and greater city of Norwalk), was supplied by one of the two lighting companies, located in the, then, separate municipality of older Norwalk. Competition continued for a while, but eventually a merger gave the enlarged company a monopoly of the local electric lighting business.

The street lighting service, however, which had been unreliable and frequently out of commission before, did not show improvement under the new combination. Consequently the already well grounded dissatisfaction of the South Norwalk people increased, and they also claimed that the cost was excessive. Strenuous complaints poured into the administration and were vigorously pressed upon the company; but all appeals seemed only to reach unresponsive ears. For the company, though handicapped by inadequate facilities and apparently scant finances, neither took the public into its confidence nor made any promises for betterment, but seemed to feel too fully 
in control of the local field to realize the need of giving heed to the growing seriousness of the situation.

Undoubtedly a little tactfulness and reasonable conciliation then would have saved the day for it, as the progressive spirit of the community simply wanted the good reasonable service to which it was entitled. In those days the excellent public utilities commission of the state, which could now act with fairness to both sides of such an issue, had not been created.

Finally it was suggested that the city might solve the problem by building an electric lighting plant of its own. Thus municipal ownership was forced to the fore, not by choice, but as a sole alternative. This scheme, with little or no solid support at first, gradually resolved itself into a serious discussion and sides were taken. Considerable of the lighting company's stock, which it is understood had as yet yielded no dividend, was owned in South Norwalk. Consequently the city became divided on the subject and political lines gave way to those for and those against the object in view.

Conditions so continued for over a year, except that in the meantime the common council managed to appoint a committee to look into the practicability of a suitable municipal street lighting plant. This committee of unbiased men, regardless of the tense feeling both ways, went into the matter deliberately and thoroughly. They spared neither time nor the expenditure of their own money in investigation, which in the end, at almost no cost to the city resulted in a favorable report. Bitter contention was caused thereby between the opposing forces that almost brought the issue to a manto-man affair. Families were divided and life long friends lined up against each other.

The company, still slow to grasp the situation, instead of coming forward with overtures, treated the matter as a threat that would not materialize and heaped ridicule upon it, while the service grew worse. Aside from the company, even the other chief opponents stuck to the belief that after a certain amount of excitement had been indulged in the proposition would die out.

A few sturdy citizens, however, thought otherwise-one of them, now in Congress, the Hon. Jeremiah Donovan, we call him "Jerry" now as we did then, was the people's champion. Early in 1892 a monster mass meeting was called, after a number of others that had failed to take active measures, and "Jerry" addressed the multi- 
tude giving vent to his convictions in favor of the municipal plant in one of the most powerful appeals to reason in the history of the spirited little city. In summing up he showed that it was the only way open to obtain proper service under the circumstances, and urged immediate action. The result was a rousing vote for a street lighting plant, carrying an appropriation of $\$ 22,500$, to be borrowed on bonds, and the appointment of a construction committee to build it.

The company presently awoke enough to the fact that the people were in earnest to become active with injunction processes, breach of contract and other suits carrying staggering claims for damages. It even hampered the committee by endeavoring to dissuade makers of the necessary electrical apparatus from selling to the city. Thus did the company, whose short-sighted policy alone had forced its own community into municipal ownership in order to secure the adequate electrical service upon which, as a growing manufacturing and commercial center, its progress was largely dependent. As to the necessary electrical apparatus, the committee declared, if it could not buy it, it would make it. And so the cold footed manufacturers warmed up and the machinery was bought.

Regardless of threatened law-suits, predictions that the plant could not be built for the money appropriated, nor operated at the low cost that had been estimated, the committee kept right on, too busy to be swayed either by the direct and indirect ways by which the sore opposition tried to block the way, or by those, most of all, distracting head-shakings of the neither-one-thing-nor-the-other fence perchers.

The company solicited influences from a distance to aid it in crying down the public plant proposition. Bad examples were exhumed and enlarged upon; exaggerated reports of failures elsewhere were kept in evidence, but that committee of three strong men, General Nelson Taylor, a dauntless warrior of many battles and a lawyer of record; ex-Mayor Edwin Adams, a manufacturer of prominence and a man who knew not defeat when he thought he was right, and Councilman Joseph A. Volk, likewise a manufacturer and a man of set convictions that won respect, knew only how to go ahead, not backward. Only the last named is now living, and of the good work they did, their only questionable act was in choosing their engineer, but, contrary to my protests, they would accept no refusal, so I accepted. All served without other compensation than the 
consciousness of doing one's best, and, with more than $\$ 2,500$ of the appropriation still untouched, on Friday, the thirteenth of October, 1892-mark well the day and date, ye superstitious,- South Norwalk blazed forth brighter than she had ever been before at night, and proclaimed her ability, under stress of circumstances, to banish the shadows of doubt, as to her capacity to penetrate dire opposition to her progress, with her own home-made brand of enlightenment.

The first shot of April 19, 1775, at Lexington, for the independence of this blessed country of ours, sounded around the world. And so the lights of South Norwalk have won her fame as an example of the cause and effect of forced municipal ownership, and a success that just had to result.

Investigators, scientists, delegations from afar have visited this little plant and have found it a plain affair, not ornamental, but full of usefulness. Those in favor and those opposed to municipal ownership have gone away both satisfied that it is just a simple business undertaking that has made good.

Within the year after South Norwalk became the first city in Connecticut, and one of New England's pioneers, to enter the municipal electric lighting business, the fear of the privately owned similar interests became so great that they were instrumental in having a law passed by the legislature to protect them from encroachments, upon their monopoly, by municipalities. With regard to fair dealing companies, this act is harmless, but under it the people have scant redress from the shortcomings of any concern inclined toward hidden unscrupulous ways which might be difficult to expose. After the passage of this act an attempt, as serious as it was ridiculous, was made to scare the South Norwalk people into a desire to dispose of their electric plant on the pretext that, not having been created under the requirements of the act, it was therefore operating illegally. When attention was directed to the fact that the plant had been completed and placed in regular service many months before the act became a law, this bug-bear faded away. This is only a single instance of the countless traps and obstructions that were laid in the path of those who fostered this infant undertaking of the people. But they had their good effect, after all, for they kept its sponsors constantly on the alert. "Eternal vigilance" was the watch-word and determination not to fear prospective defeat kept nerves and 
intelligence at high tension. Thus many malicious schemes were scented before they became visible, and were quietly treated in a way that discouraged maturity.

Though previously, and for sometime afterwards, affiliated with private ownership of electrical undertakings, and always the friend of well serving privately owned public utilities, I identified myself with the people's cause in South Norwalk's instance, from the very outset, not as an advocate of municipal ownership, but because I was deeply attached to the little city whose future seemed most promising, and realized how essential good electric service was to her progress. Being thus identified with this work, there was no choice for me but to pursue it to the best of my limitations. The fact that some ill-advised friends of mine, of the opposition, threatened me and told me my future was ruined, simply clinched me to my purpose, so I just stuck to the ship. All those unpleasant feelings have died away, because only the good endures, and those who misjudged me are my good friends now for all time, I hope. Further than this purpose, I harbored a belief that civic governmental functions and good business methods could be combined with resultant public benefit.

I know of nothing better than honest private ownership of public utilities under just public regulation and protection, yet the right of the public to do its own work, if local conditions and the best public good depend upon such alternative, must be recognized.

Having thus been forced into the issue, the study of public utilities and their operation followed, and the question resolved itself more and more into the single object of best service for the public, rather than that of ownership.

To be consistent, therefore, I had to help make South Norwalk's justified venture into this branch of municipal ownership as serviceable, as businesslike and as honestly successful as I knew how. So I made a little pledge, all to myself, that I would try to stick by it until it should be entirely free from debt. Now it represents, with all its enlargements, an investment of over $\$ 205,000$, but on the eleventh day of October, 1913, it stood clear of debt; every dollar of its investment having been paid back from its net profits from commercial sales alone, just two days before it was twenty-one years old, and never one cent of taxation. Was it a "civic mistake?" A great friend of mine, connected with one of the largest companies 
in the world, that supplies electricity in one of the world's largest cities, and one of the best fellows in the world, an ardent opponent of municipal ownership, has said so. Perhaps he is right. At any rate, my pledge has been filled and I am free. During the last fiscal year the little plant has also paid dividends of its profits into the municipal treasury, equal to $\$ 1$ per capita of its district of supply, for the public good. In its paid-up sinking fund for the only bonds it ever issued, of only $\$ 42,500$, are $\$ 25,000$ worth of its own city's bonds that it has been able to buy in at a bargain, by carefully watching the bond market.

And now from its reserve funds, which are building up at a nice rate, it loans money to its municipality as needed and without interest. The citizens at present are contemplating the use of its surplus profits to buy in the former city's outstanding street paving and other municipal improvement bonds, thereby reducing the municipal debt. Today, the section of the new city-the most thickly settled part, the main business center, the wealthiest district of the three that contain the densest population and most valuable industries-that has the lowest tax rate is the district that was the city of South Norwalk.

When occasionally asked to decide between public and private ownership, if given an opportunity to weigh the relative conditions, I try to return a decision that I sincerely think will produce the best result, with as careful consideration, for the future as present and past contrasting conditions will permit. In instances approaching similar conditions to those that South Norwalk had to face, it has been in favor of municipal ownership, but in many other instances it has been emphatically the other way. Cases like South Norwalk's, thanks to a growing efficiency in administration, state and city, are rare and becoming more remote.

Confiscation of rights that have been given by the public, accepted in good faith and honestly capitalized, with a reasonable expectation of a fair return for services properly rendered, is unjustified.

Even if the service deteriorates, every possible effort to induce a remedy should be resorted to before public replacement is considered. Regulation is superior to revolution, but revolution certainly is an alternative, though a grave one of final resort. 
For years South Norwalk was sorely burdened with law suits, instituted by the competitive company, intended to constantly hamper and, ultimately, abolish the municipal plant. At some stages matters looked dark, indeed, and some of the more timid citizens predicted that the company-which had subsequently become a part of a great corporation with powerful influences at its call-would win and bankrupt the city, for the damages that it held over our heads were enough to make stout hearts quake. Threats to put the little plant out of business by rate cutting and injunctions against its enlargement were common. But the company was told to go ahead and, if it could beat the low scale of the municipal plant, the latter would close its doors and rest while the company's generosity lasted, as the chief aim of the municipal plant was simply to render the best service at the lowest cost, and the citizens would deem their investment in the plant a most satisfactory one if it could accomplish its purpose, through the medium of the company, without turning a wheel.

As for the law suits, the cost of which the plant, not the city, had to stand, our present Attorney General of Connecticut, Hon. John H. Light-note the coincidence of the name-then corporation counsel of South Norwalk, ably defended the city and rendered great service in helping to bring matters to a head so unexpected to the company, in all its newly acquired might, that it was glad to withdraw its suits of seven long years and treat for peace. Prior to this, at one time the company endeavored to influence the city to let it purchase its plant, on very flattering terms, or to lease it, but when the matter was brought before the people, they just voted to build the plant larger, and the company immediately applied for an injunction to stop the enlargement. But the work never stopped until the enlargement was ready and running.

All this time the city plant had been fighting for its right to live, but it kept on growing all the while and, by its success, gradually winning the support of even the citizens who had opposed it. But best of all, today, it is on friendly terms with the great broad-minded, progressive corporation that has succeeded its one time vindictive enemy, and coöperation reigns where bitter opposition used to control. Neither directly competes with the other; the municipal plant, supplying the central district of the city, old South Norwalk, and 
the company carrying on a prosperous business in the large territory round about. Its rates have long since been much lower than they used to be, and its service is excellent.

But to show how progress was made we must go back some years into the trying times. By vote of the people, commercial electric lighting under a $\$ 20,000$ bond issue was added to the city's street lighting system in 1898, because the company, even after six years, had failed to properly fill the growing need for that class of service. While the addition was being built, the company put up such a fight and scared the people so badly, that the municipal plant, out of all the promises that had been made to take its service, only succeeded in obtaining six patrons to start with. But it did start, just the same, and ran at a dead loss for some months. And it was amusing to hear the comments when the few places that had the city lights were the only bright spots to be seen when the lights of the company would die down and stay dim, or go out entirely, as they frequently did. Hence oil lamps and candles, for emergency service, were the usual thing in the stores, and had forced the city to go into the commercial lighting business also.

Before the year was ended, however, the city plant had won a goodly number of patrons and gained rapidly thereafter.

As the company had made no visible effort to cater to the pressing need for commercial electric power service, the city plant encouraged it, and, after considerable experimenting, added it as a regular feature in 1901, taking on about 15 horse-power in motors to start with. The company made some arrangements to compete with the city plant in the power business, but encountering an obstruction which was discouraging to its plans, and as the city plant was much ahead in the race, it sold out, at a modest figure, to the municipal plant.

Though hotly contested by the company, each new venture of the little plant soon proved worth while. And at the present time, electricity, generated by South Norwalk's electric works, turns more wheels of industry within its territory than any other force, having on its lines motors aggregating a total of about 1200 horse-power, And the factories have increased at a healthy rate since the power service was established.

During the twenty-two years' life of this plant, the population of South Norwalk has doubled. 
When the city's commercial lighting service was installed, only one residence in the city had used electricity for that purpose up to that time. No others could get the company to supply them and the total incandescent lamps then on the company's lines in South Norwalk were only about 1,500 ; all that the company claimed it could allow in its South Norwalk district, by reason of insufficient generating facilities. Therefore, many houses and other places that were wired and ready for it could not get the service. Today, in an area whose population is estimated at about 11,000 , more than 25,000 city lights bring cheer to hundreds of homes of the prosperous and humble alike and are universal in all manner of business and other places where electric lights are used.

To meet the continually increasing demands for its service, the plant has been enlarged six times and is thirteen times its original capacity. At one time I had to undergo a rather embarrassing investigation, by a committee appointed by the mayor at the behest of some good citizens, because a belief had gained ground that I was responsible for more frequent enlargements of the plant than seemed justified. But the enlargement then needed was not only built, but the committee added to it. Other enlargements have since been built without a question.

Now past twenty-two years old, representing an investment of about $\$ 205,000$ in round numbers, originally capitalized by an issue of $\$ 22,500$ bonds for the street lighting system and a few years later by an additional issue of $\$ 20,000$ for the commercial addition, making a total actual capitalization of $\$ 42,500$, this plant has taken care of every subsequent investment with no other aid than its actual surplus profits. Not only that, it has provided a fully paid-up sinking fund for the $\$ 42,500$ bond issues, from the same source, and is getting an interest return from the sinking fund that will pay the interest on the bonds until they mature. Aside from now turning money into the local treasury for such use as the citizens may decide, it has always supplied the street lighting service on a basis of cost, so no profit has been derived from that source; therefore, by reason of that one item alone, many thousands of dollars have been saved to the taxpayers, perhaps more than the total bond issues.

The question is sometimes asked, why has South Norwalk succeeded in the municipal ownership lighting field, while some other places have not been so fortunate. In reply to this it may be truly 
said that undoubtedly many cities can show results as good and possibly better. Unfortunate examples, however, are most talked about, especially by those who delight in harping upon the negative side of issues to which they are interestedly opposed, and prominence so given may be mistaken for numbers. The truth only should be accepted, not opinions, when the truth can be ascertained, and anything that cannot stand without it should fall, be it municipal ownership or anything else.

With regard to South Norwalk's case, passing over the important fact that her people have always kept themselves in touch with their civic duty, that she also has a water works system that is surpassed by none of its size in excellence of service, liberal rates and profitableness, a much older institution than the electric works, that supplies the finest filtered water-even for quenching fires-and at a pressure that requires no fire pumping engines, her good fortune so far in municipal ownership may be traced to her long record of clean administration methods, putting men of honor in office, and to a sincere effort to start right and keep right whatever she has undertaken.

From the beginning her public utilities have been protected from politics; that arch defiler of all kinds of public utilities regardless of ownership-public or private. Political manipulation has not yet been able to take root in this instance. Suffice it to say that it has attempted to sow its seeds, but, fortunately, the weeds have been recognized while tender enough to yield to the first proper "pull"-the persuasive pull of public objection.

The commissioners, in charge of the electric works, selected with care as to fitness, are elected by the people and may expect to be returned to office, if willing, as long as they carry out the will of the people. They are prohibited from holding any other municipal office and are organized just like the directors of a private enterprise. Each is skilled in mechanics and is a successful business man. Therefore, they are not at sea with the responsibility of their office.

Frederick Hunkemeier, president; Thomas Robins, treasurer; and Patrick F. Brophy, secretary; each springing from a different nationality, of differing political leanings, thus they constitute a truly $E$ pluribus unum board and, consequently, very much American. Being nominated by agreement between the political parties, upon a non-partisan basis, they are free from contact with or influence by 
the political machine. Even the political paths of their employees are unasked and unknown.

As their active representative, they appoint a general superintendent, which position your humble servant has always had the honor to hold; although he, also, served as one of the first commissioners for about ten years, but resigned that office when the increasing duties of operative management finally demanded bis full time and a separation from the board. He is given great liberty of action and is expected to produce good results.

Open business methods in conducting the plant and always spreading its doings upon the wings of publicity have kept it under the eye of the people. Everything about it of interest is gleaned by the local press and served up in a way that keeps all watchfully and friendly interested in its progress, its needs and prospects. When any doubt has arisen as to its doings, public investigation has been demanded by its commissioners or its superintendent, and everything has been thrown open, so that praise instead of censure has been accorded its management.

Thus suspicion, that follows insufficient knowledge, has had no soil in which to thrive, and the people feeling satisfied, have encouraged those, whom they have placed in charge of their undertaking, to do their best and good has naturally resulted. Nothing is so well guarded as that thing of undivided ownership, that stands in the open, upon which all eyes are turned.

Whether it be privately or publically owned, that public serving utility which is kept closest to those it serves inspires confidence almost without effort, and builds around itself an element of coöperative sympathetic interest that will protect it from imposition and the injustice due to ignorance and consequent suspicion, more effectually than the written law.

For years South Norwalk's electric service rates were widely accepted as the lowest in this country and until the advent of the great super-excellent modern hydro and steam turbine driven, high efficiency generating stations, which of late have served such a grand purpose in the reduction in the cost of production, which has brought remarkably low rates to the localities thus favored. But her schedule is still among the lowest, especially in the eastern section of the United States, with particular regard to the small consumers and moderate industrial requirements, to which she carefully caters, 
believing that the little fellows are the ones who should be most nurtured, for they are the "acorns from which great oaks grow." Thus the South Norwalk Electric Works, though one of the smaller undertakings of its kind, and entirely dependent upon fuel for its motive power, holds its own fairly well with its greater and newer equipped contemporaries. With them it is in no wise competitive, neither does it seek antagonistic comparison with any similar undertaking, private or municipal, but desires to coöperate with all in bringing about the most public good, hence the most good for all.

South Norwalk's rates-which may be raised or lowered by the commissioners or vote of the people-are as follows:

For regular municipal service: Street lighting, from dusk to dawn every night by the standard 4,000 hour yearly schedule, per lamp per year-at estimated cost.

Arc lamps, enclosed arc or magnetite, $1 \$ 54$.

Incandescent Mazda high efficiency lamps, not exceeding 70 watts, $\$ 10.80$.

Municipal buildings, by meter at actual cost per kilowatt hour, between 2 and 3 cents.

For commercial service: the gross monthly charge for lighting is graded from 9 cents down to 5 cents per kilowatt hour; after 500 kilowatt hours have been used, the rate continues at 5 cents during that month; the minimum monthly gross bill for lighting is 55 cents. All commercial lighting bills are subject to a discount of 10 per cent from the foregoing, if paid in 10 days.

For commercial power service: the gross monthly charge for motors, cooking, heating and all purposes, except regular lighting, is graded from 5 cents down to 3 cents per kilowatt hour; after 500 kilowatt hours have been used, the rate continues at 3 cents during that month; the minimum monthly gross bill for lighting is $\$ 1.11$; all power bills are subject to a discount of 10 per cent from the foregoing, if paid in 10 days.

No distinction in rates is made between mercantile and domestic service.

Arc lamps are loaned and maintained free of cost, if desired.

Carbon incandescent lamps are supplied free.

No charges for service connections, unless difficult of access.

No charge for removing, changing or replacing meters, as desired.

No charge is made for meter testing as required.

No supplies are sold, except Mazda lamps-at less than cost, and fuses for emergency; thus in having their electrical work done and purchasing supplies, fixtures, etc., the consumers enjoy the variety and competition of a goodly number of electrical dealers and wiremen.

All electrical installations are required by ordinance to be inspected by and approved by a municipal inspector, independent of the Electric Works.

${ }^{1}$ The arc lamps have been recently extensively superseded by Mazda lamps at shorter intervals with marked improvement, and an elaborate scheme of ornamental street lighting is under consideration. 
No contracts are required for the supplying of lighting or power; any consumer is free to use the service or not, at will, after being connected, and simply pays for what has been used.

There are no conditional charges, based upon special service, periodical conditions, kilowatt capacity, nor for break-down service; whenever the service is turned off, the cost to the consumer stops, and if no service at all is used, only the nominal monthly minimum charge is required as long as the meter is retained, to cover its investment, reading, maintenance of the service, etc.

An advance payment, about sufficient for one month's service, or a suitable endorsement, is required from patrons who do not own local real estate. This payment is subject to return upon closing the account, unless needed for arrearage.

No person, high or low, receives free service. Even the municipality pays the Electric Works for value received and in turn collects, at full rates, for the considerable water service used by the Electric Works and for any other service involving expense, so rendered; except that no tax is required in pursuance of a state law, but the fact that the street lighting and other municipal service, supplied by the plant, are rendered on the basis of cost, the municipality is thus far more than compensated for any loss of taxes.

Free lighting, however, is donated temporarily to civic and other functions for the public good and charitable purposes.

The Electric Works operates and maintains the municipal fire alarm and police telegraph systems, at actual cost for labor and material, and has had full supervision of same for many years, including the announcing of standard time on the fire bells at noon and 8 p.m. daily; the latter serving as a reminder of evening appointments, entertainments, etc.

This department has for many years also exercised a general supervision and regulation, in behalf of the city, relative to rights of way, locations of poles, wires, conduits, etc., of all telegraph, telephone, street railways, electric lighting and power companies, within the municipal area. Such service has always been rendered without cost to either the city or the companies, and has been the continuous means of maintaining good feelings and coöperation between all concerned, by seeing that all were served with due consideration for each other's rights, and with due regard for the public.

The electric works owns the local public weighing scales for vehicles, etc., and acts as weigher for a charge of 5 cents per load.

A majority of South Norwalk's electric lighted homes pay less than $\$ 18$ per year, and many under $\$ 10$. Modest homes using the service very extensively.

As for power, many budding factories have monthly bills of about $\$ 10$ or under, and instances under $\$ 5$ are not unusual. About $\$ 1$ per day is a fair rate for some quite important industries.

In 1908 the thriving suburb of East Norwalk-now an important section of the new city of Norwalk-established a municipal electric system of its own for both street lighting and eommercial service. $U_{1}$ to the present this 
plant has purchased all of its electricity from the South Norwalk Electric Works, but its growth has been such that it is now installing a generating station of its own and will soon be self contained.

The motive power that generates South Norwalk's "juice" consists of coal burning boilers, simple steam engines and Diesel fuel oil engines. The steam equipment, though always ready for immediate service, serves mostly as an auxiliary to take up sudden loads, to carry peak loads and for emergency service, while the oil engines carry the bulk of the load. All current is direct, as the area of supply is very densely populated and permanently confined by its charter to a territory small enough for such current to render the best and most economic service.

Without regard as to the right or wrong of municipal ownership of public utilities, its growth in this country and the interest it has aroused, in spite of the difficulties it has had to encounter, show it to be a live issue. Just a glance at the statistics on this subject is quite indicative of this fact.

For instance municipal ownership electric lighting began in this country in 1881 with a single plant, but according to the 1912 census there were 1,562 listed and the actual number now is estimated at more than 1,600. This represents a remarkable growth in a comparatively new field of municipal ownership, especially in view of the closely matched extremes of favor and disfavor that have attended it. Also that it started almost with the advent of electricity as a practical means of illumination. The statistics credit Ohio as being the banner state in municipal electric plants with its 118; Michigan has 108, Minnesota 104, Illinois 99, Georgia 84, Kansas 82, Wisconsin 78, Indiana 71, Missouri 65, Oklahoma 63, New York 49, North Carolina 48, Mississippi 47, Pennsylvania 45, Iowa 64 , Nebraska 62 ; all the other states have varying numbers from 1 to 35, except Arizona and New Mexico, which are not credited with any. In Great Britain, more than half of the public service electric plants are municipally owned.

Generally speaking, from having visited and closely studied many of the municipally and privately owned electricity undertakings of England, Scotland and Ireland, those municipally owned impressed me as eminently successful and lost no credit in comparison with similar privately owned undertakings. Both showed marked excellence in management and equipment in the aggregate.

If it is a fact that the prevailing methods of municipal administration in our country are not as favorable to efficient operation of 
municipally owned commercial public utilities as those of Europe, it is a reflection upon our fitness to undertake such responsibilities, that is neither creditable to our citizenship nor those who manage our public affairs; but it is not a fair argument against the principle of municipal ownership. Great Britain and most of the other European countries have weathered far more trying civic conditions than we have had or are likely to have, and have remedied the evils by splendid reforms, to such an extent that some of their standards of municipal administration are worthy of emulation.

Questionable politics is as detrimental to privately owned public utility institutions as it is to the municipally owned. To this cause may be traced very largely the advent of many municipal plants. For what is more in conflict with an endeavor to keep municipal administrations clean and efficient, than a great private corporation that trades with politicians?

Too much emphasis cannot be placed on the fact that public utilities, under both private and municipal ownership, offer great temptation to that element of politicians who, like birds of passage, prey greedily today upon those things which they fear may be beyond their reach tomorrow. Such men too often regard a nice public utility as a convenient sort of political patronage asset. Its economic benefit to the community concerns them as little as does its actual ownership, so long as it can be utilized for personal and party advantage. The main thing is: what is there in it for the time being that will come in handy to them?

Therefore, no public utility should ever be established under municipal ownership, unless it is to be placed above the domination of politicians and wholly under the charge of able men of known integrity. To them should be given reasonable latitude of action and they should then be held responsible for proper results, just the same as the directorate of a private corporation. Such men should hold office, wholly independent of political dictation, as long as they make good, and never more than a minority representation should be replaced at a time, so that experienced men will always be in action.

Periodic change in office is one of the greatest drawbacks to efficient and economic public administration. We simply wouldn't stand it in private business affairs. Thus men who have been educated at public expense are too often thrust out just as they have 
learned how to do their work, and other learners succeed them, very much on the my-turn-next plan of our school days, which was never intended for the serious business of manly years.

Until we have instituted needed reforms in our ways of carrying on the public's work, municipal ownership, to replace private ownership on any extended scale, should be considered most carefully before its adoption even as a final alternative. Otherwise a simple change of ownership may result not only in a swopping of evils, but plunge communities into debt, litigation and responsibilities, which they may be unfit to bear; not to mention the ruination of investments.

Before municipal ownership as a commercial business is decided upon, it should be determined without prejudice, by unbiased trustworthy persons, whether or not it is the best alternative. Neither fancied reasons, theories, snap-shot judgment, spite nor a personal grouch, should be allowed in evidence. Both public and private interests have paid heavy toll, and will continue to do so, because people do things collectively under lack of personal responsibility and unwise infuences, from which, as individuals, they would shrink. Majorities may be wrong.

Therefore, though it may be proven that a privately owned public utility has failed in its obligations to the extent that public ownership seems to be the only remedy, even then every reasonable means should be used to induce and aid the local concern to meet its just requirements. It is wiser to patiently pursue a determination to improve existing methods, than to multiply public burdens and responsibilities unnecessarily; and only communities that can thus consider this matter are fit to be trusted with extended responsibilities.

The municipalizing of any form of money earning public utility carries with it great possibilities for good or evil. "What is medicine for one is poison for another," was never more applicable than to municipal ownership. Every community stands alone and must meet the issue according to the merits of its own peculiar conditions and expectations.

The possibility for any municipality to have some time a municipally owned public utility is ever in the offing, as a final resort, and should be so considered. The public utilities commissions or equivalent bodies, in most states, stand ready to act intelligently upon this issue. This being so, all that is needed is a just cause 
and a unity of purpose to bring about the regulation or the alternative.

Community ownership is not new, it goes back to the time when man grasped his reason, as a staff, and raised upon his hind legs above the other animals. Realizing that he needed protection and feeling the strength of numbers, he became a social being, and the community was established. The community discovered, and comprehending its value to all, set aside a spring for the use of its people, and we have the embryo public water works. At night, so that they might not be surprised by the enemy, for greater convenience in moving about and to prevent mistaking each other in the dark for a foe, they set up a beacon and the watchers-the first of the "finest"-kept it alight.

Thus came the public lighting plant. Time has simply added refinements. While so busy giving away valuable public service franchises, we Americans seem to have forgotten that community ownership was all there was for us to rely upon at one time for the few crude public conveniences and necessities that we jointly enjoyed.

Private ownership is comparatively new. Under it wonderful improvements have been developed for our common comfort and progress, that otherwise, very probably, might not have arrived so soon. We owe it deep gratitude. If it has sometimes given short measure, have we been as fair of measurement as we should have been-We, the public? Have we not ourselves to blame for a laxity that has tempted those who have served us, to be lax? It is mighty nice to be waited on, but if we indulge too much in such luxury, we become less handy in waiting on ourselves. Thus public ownership has in a measure slipped away from us, for a good and natural reason, so quietly that we haven't realized it. If a servant assumes the mastership, whose fault is it? The master's or the servant's?

To say that either private or public ownership is most wrong and that only one is most right, because the advocate of one or the other says so, is about as reasonable as for the follower of one faith to say that his is the only road to heaven. All things gain or lose by contrast. The glorious light of day would be bare of glory, were it not for the blackness of night. And the enchanting peaceful restfulness of the mystic night would be hideous were it not for the glare and toil and blare of the noisome day.

Why not submit to the fact that both private and municipal 
ownership survive, and each having honest adherents indicate that both have legitimate fields to fill. We are to have both according to our requirement, actual or apparent, until the need of one or the other is proven by results.

The people are the paymasters and they generally get what the law of supply and demand, that they have created, offers them. If they want something better, good mastership demands that they devote their energies and intelligence to the cause of just regulation of, and protection to, the interests that they have created to serve them, and not to everlasting differing views as to whether private or public ownership is best, with each side of the issue hostile to the other. Good service is, or should be, the aim of each. 